\title{
CONVOLUTIONAL NEURAL NETWORK UNTUK KALASIFIKASI PENGGUNAAN MASKER
}

\author{
Arham Rahim ${ }^{1}$, Kusrini ${ }^{2}$ Emha Taufiq Luthfi ${ }^{3}$ \\ Megister Teknik Informatika, Universitas AMIKOM Yogyakarta ${ }^{1,2,3}$ \\ Email : arham.rahim@students.amikom.ac.id¹, kusrini@amikom.ac.id², \\ emhataufiqluthfi@amikom.ac.id ${ }^{3}$
}

\begin{abstract}
ABSTRAK
Coronavirus Disease-2019 (COVID-19) merupakan coronavirus jenis baru yang menjadi pandemi di berbagai negara. Salahsatu upaya pemerintah dalam mencegah penularan virus ini adalah dengan mewajibkan masyarakat untuk menggunakan masker serta memantau penggunaan maskar oleh masyarakat dalam kehidupan sehari-hari. Ketidak patuhan masyarakat menjadi masalah dalam mencegah penyebaran virus ini sehingg membutuhkan sebuah sistem yang dapat melakukan pengawasan. Pada penelitian ini, dibangun sebuah model dengan dengan memanfaatkan algoritma Convolutional Neural Network (CNN) dan 1000 dataset untuk melakukan pelatihan terhadap sistem deep learning serta melakukan pengujian untuk mendapatkan nilai akurasi dari hasil klasifikasikan terhadap gambar wajah yang menggunakan masker dan tanpa menggunakan maskaer. Hasil penelitian ini menunjukkan skenario kedua yang menggunakan epoch 50 dan rasio dataset $90 \%$ data latih dan $10 \%$ data uji mendapatkan akurasi terbaik mencapai 96\%. Pengujian pada gambar wajah yang menggunakan masker memperoleh nilai precision $98 \%$, recall $94 \%$ dan gambar wajah yang tidak menggunakan masker memperoleh nilai precision 94\%, recall 98. Skenario satu dan tiga memperolah nilai akurasi terendah yaitu 94\% sehingga dapat disimpulkan bahwa jumlah data latih sangat mempengaruhi nilai akurasi.
\end{abstract}

Kata Kunci: CNN, Deep Learning, Image Processing.

\begin{abstract}
Coronavirus Disease-2019 (COVID-19) is a new type of coronavirus that has become a pandemic in various countries. One of the government's efforts to prevent the transmission of this virus is to oblige people to wear masks and the use of masks by the community in their daily lives. Community disobedience is a problem in preventing the spread of this virus, so it requires a system that can conduct surveillance. In this study, a model was built using the Convolutional Neural Network (CNN) algorithm and 1000 datasets to conduct training on deep learning systems and conduct tests to get the value of the classification results of face images using masks and without using masks. The results of this study indicate a second scenario using epoch 50 and a dataset ratio of $90 \%$ training data and $10 \%$ test data, the best accuracy reaches 96\%. Tests on facial images using masks to get $98 \%$ precision value, $94 \%$ recall and face images without using masks get $94 \%$ precision values, recall 98. Scenarios one and three ways get the lowest value of $94 \%$ so it can be seen that the amount of training data greatly affects the value of the language.
\end{abstract}

Keywords: CNN, Deep Learning, Image Processing. 


\section{PENDAHULUAN}

Corona Virus Disease-2019 (COVID19) adalah koronavirus jenis baru yang ditemukan pada Desember 2019 di Wuhan Cina. COVID-19 menjadi pandemi di berbagai negara seperti Amerika Serikat (US), Inggris, Italia, Thailand, Singapore, Malaysia dan berbagai negara lain termasuk Indonesia. Menurut Badan Nasional Penanggulangan Bencana (BNPB), perkembangan COVID-19 di Indonesia sejak maret sampai 14 Mei 2020 tercatat 16.006 kasus positif dan 1.043 dinyatakan meninggal dunia. Menurut World Health Organization (WHO) jumlah kasus positif COVID-19, Indonesai masuk dalam peringkat 35 dari 215 negara dan wilayah/teritorial.

Cepatnya penyebaran virus hingga banyaknya korban jiwa, memberikan dampak negatif bagi kehidupan bermasyarakat menjadi masalah yang sangat serius bagi setaip negara sehingga membutuhkan penangan yang serius pula untuk mencegah semakin meluasnya punalaran COVID-19. Salah satu alternatif pencegahan penularan COVID-19, pada 6 April 2020 World Health Organization (WHO) mengeluarkan anjuran penggunaan masker di tengah masyarakat, selama perawatan dirumha dan ditempat pelayanan kesehatan yang diperuntukkan bagi anggota masyarakat, tenaga profesional kesehatan masyarakat dan pencegahan dan pengendalian infeksi (PPI). Berdasarkan rekomendasi anjuran tersebut, pemerintah Republik Indonesai mewajibkan warga untuk menggunakan masker saat beraktivitas diluar rumah. Akan tetapi, ketidak patuhan sebagain masyarakat terhadapat protokol kesehatan sebagai upayah pencegahan penularan COVID-19, menjadi keresahan bagi masyarakat secara umum. Menurut (Astiningsih, Kurniawan, \& Suroto, 2018)Kurangnya inspeksi dan pengawasan yang mencapai $72 \%$ mengakibatkan $54 \%$ pekerja tidak menggunakan APD.Sehingga memerlukan inovasi berupa sistem pengawasan yang real time dan secara otomatis dapat mendeteksi para pekerja yang tindak menggunakan APD.

Pemanfaatan teknologi untuk melakukan pengawasan dilakukan oleh (Fang, Ding, Zhong, Love, \& Luo, 2018) dengan mendeteksi secara otomatis pekerja dan alat berat di lokasi konstruksi menggunakan algoritma Convolutional Neural Network (CNN) Penelitian ini mampu mendeteksi keberadaan pekerja dan excavator dengan akurasi mencapai $91 \%$ dan 95\%. Dan (Fang et al., 2019) juga melakukan pengawasan dengan mendetekasi pekerja yang melakukan prilaku tidak aman seperti melintasi structural supports (beton atau baja) pada konstruksi bangunan menggunakan algoritma Convolutional Neural Network (CNN) Penelitian tersebut menyimpulkan tingkat penarikan dan presisi untuk deteksi yang tumpang tindih mencapai $75 \%$ dan $90 \%$..

(Chen, Tong, Chen, Fang, \& Liu, 2018)Penelitian ini melakukan dua skenario pengujian dimana skenario pertama hanya menggunakan algortma CNN dan skenario kedua menggunakan algoritma CNN untuk ekstraksi fitur dan SVM untuk melakukan klasifikasi gestur tangan dari sinyal Surface Electromyography (sEMG). Dari hasil penelitian ini, penggabungan CNN-SVM memperoleh akurasi lebih tinggi yaitu $68,2 \%$ dari skenario pertama dengan 
akurasi 65,4\%. (Chaiyasarn et al., 2018) Penelitian ini bertujuan untuk mendeteksi retakan pada struktur batu di sutus bersejarah menggunakan algoritma $\mathrm{CNN}$ untuk mengekstraksi fitur dari gambar RGB dan menggunakan algoritma SVM untuk proses klasisfikasi. Penelitian ini juga menggunakan dua skenario pengujian dengan membandikan akurasi dari proses yang hanya menggunakan algoritma CNN dengan CNN-SVM. Penelitain ini menyimpulkan gabungan CNN-SVM lebih baik dengan akurasi dari validasi dataset $85,94 \%$ dan testing dataset $74,9 \%$ daripada CNN dengan akurasi validasi dataset $82,94 \%$ dan testing dataset $67,5 \%$.

(Yaqi Wang, Sun, Ma, \& Fang, 2018) Penelitian ini bertujuan untuk mengklasifikasi gambar mikroskop kangker payudara menggunakan algoritma CNN dan SVM. Dengan menggunakan skenario yang sama, penelitian ini memperoleh hasil yang berbeda dengan dua peneliti sebelumnya (Chen et al., 2018) dan (Chaiyasarn et al., 2018)penelitian ini menyimpulkan hasil klasifikasi gambar menggunakan algoritma $\mathrm{CNN}$ lebih tinggi dengan nilai akurasi $92,5 \%$ dari hasil validasi dataset dan data testing $91,7 \%$ daripada $\mathrm{CNN}+\mathrm{SVM}$ dengan nilai akurasi $82,25 \%$ dari hasil validasi dataset dan $80,6 \%$ untuk data testing

Beberapa penelitain sebelunya yang berhasil melakukan pengawasan terhadap objek tertentu sehinggan kami melakukan penelitian dengan memanfaatkan Convolutional Neural Network (CNN) untuk melakukanklasifikasi gambar seseorang yang menggunakan masker dan tidak menggunakan masker sebagai upayah pemanfaatan teknologi untuk mencegah penularan COVID-19.

\section{LANDASAN TEORI}

3.1 Convolutional Neural Network

Convolutional Neural Network (CNN) adalah salah satu algoritma deep learning yang digunakan untuk kasus-kasus penggunaan computer vision seperti mengklasifikasikan gambar atau video dan mendeteksi objek di dalam gambar atau bahkan wilayah dalam gambar(Moolayil, 2019). Dan menurut (Zufar \& Setiyono, 2016) CNN adalah variasi dari Multilayer Perceptron (MLP) yang terinspirasi dari jaringan syaraf pada manusia. $\mathrm{CNN}$ merupakan suatu layer yang memiliki susunan neuron 3D (lebar, tinggi dan kedalaman). Lebar dan tinggi merupakan ukuran layer sedangkan kedalaman mengacu pada jumlah layer.

\subsection{Confusion matrix}

Pada penelitian ini, Confusion matrix digunakan untuk melakukan visualisasi dari hasil penilaian kinerja pengklasifikasi. Dalam tugas multi-klasifikasi gambar, Confusion matrix menampilkan setiap hasil kelas dan membandingkan hasil klasifikasi dengan nilai yang sebenarnya. Proses ini tidak hanya menganalisis accuracy klasifikasi tetapi juga menghitung indeks lain, seperti precision, recall, dan f1score(Yu Wang et al., 2018).Accuracy adalah rasio prediksi yang benar (positif dan negatif) terhadap keseluruhan data. Precision adalah rasio prediksi positif benar dibandingkan dengan hasil prediksi positif secara keseluruhan. Recall adalah rasio positif benar dibandingkan dengan semua data positif. F1-score adalah perbandingan average precision dan recall(Patil \& Nemade, 2017). Berikut ilustrasi tabel confusion matrix seperti Tabel 1 dibawah ini: 
Tabel 1 Definisi Istilah Confusion Matrix

\begin{tabular}{|l|l|}
\hline & \multicolumn{1}{|c|}{ Definition } \\
\hline $\begin{array}{l}\text { True Positive } \\
\text { (TP) }\end{array}$ & $\begin{array}{l}\text { Jumlah } \\
\text { tersebutdianggap } \\
\text { positif. }\end{array}$ \\
\hline $\begin{array}{l}\text { True Negative } \\
(\mathrm{TN})\end{array}$ & $\begin{array}{l}\text { Jumlah tersebut } \\
\text { dianggap negatif. }\end{array}$ \\
\hline $\begin{array}{l}\text { False Positive } \\
\text { (FP) }\end{array}$ & $\begin{array}{l}\text { Jumlah data positif } \\
\text { yang tidak diklaim. }\end{array}$ \\
\hline $\begin{array}{l}\text { False Negatif } \\
(\text { FN) }\end{array}$ & $\begin{array}{l}\text { Jumlah data negatif } \\
\text { yang tidak diklaim. }\end{array}$ \\
\hline
\end{tabular}

$$
\begin{aligned}
& \text { Precision }=\frac{T P}{T P+F P} \\
& \text { Recall }=\frac{T P}{T P+F N} \\
& F 1=\frac{2 * \text { Precision } * \text { Recall }}{\text { Precision }+ \text { Recall }} \\
& \text { Accuracy }=\frac{T P+F N}{T P+T N+F P+F N} 100 \%
\end{aligned}
$$

\section{METODE PENELITIAN}

Dalam percobaan ini kami mengklasifikasikan gambar wajah yang menggunakan masker dan tidak menggunakan masker dengan menggunakan algoritma Convolutional Neural Network (CNN)

\subsection{Pengumpulan Data}

Dataset yang digunakan pada penelitian ini diperoleh dari https://www.kaggle.com/wobotintelligence /face-mask-detection-dataset yang menyediakan 4326 gambar yang terbagi kedalam lima kelas

\subsection{Pre-prosesing Data}

Setelah mendapatkan dataset, selanjutnya dilakukan proses pembersihan data karena dataset yang diperoleh terbagi kedalam lima kelas dan terdapat beberapa gambar yang memiliki kelas ganda. Proses pembersihan data dilakukan dengan memilih gambar serta melakukan croping untuk mendapatkan gambar wajah seperti pada gambar 1. Selanjutnya data dipisahkan kedalam folder berdasarkan kelas data. Proses ini mengasilkan 1000 dataset yang terbagi menjadi 500 dataset dengan label mask dan 500 non mask.

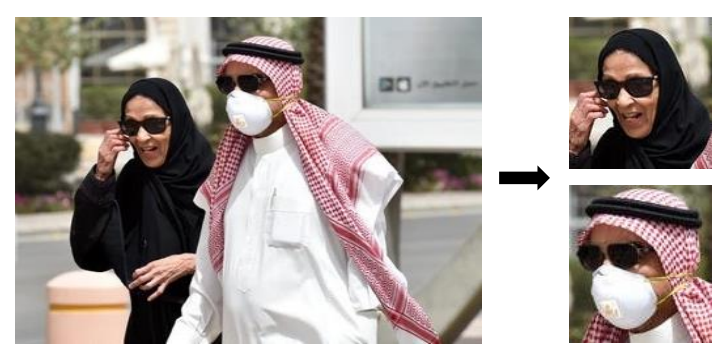

Gambar 1.Croping Gambar

\subsection{Skenario Pengujian}

Penelitian ini menggunakan dataset sebanyak 1000 gambar wajah yang telah melalui proses pembersihan dan selanjutnya diklasifikasi menggunakan algoritma CNN dengan menggunakan empat skenario pengujian. Setiap skenario akan ditentukan nilai epoch dan rasio dari data latih dan data uji. Skenario tersebut dapat dilihat pada tabel 2 .

Tabel 2. Skenario Pengujian

\begin{tabular}{cccc}
\hline Skenario & Epoch & $\begin{array}{c}\text { Data } \\
\text { Latih }\end{array}$ & $\begin{array}{c}\text { Data } \\
\text { Uji }\end{array}$ \\
\hline S1 & 50 & $80 \%$ & $20 \%$ \\
S2 & 50 & $90 \%$ & $10 \%$ \\
S3 & 100 & $80 \%$ & $20 \%$ \\
S4 & 100 & $90 \%$ & $10 \%$ \\
\hline
\end{tabular}


Dari empat skenario, dua epoch diberi julah 50 dan dua epoch lainya diberi jumlah 100. Epoch yang sama dibedakan dari rasio dataset yang digunakan.

\section{HASIL DAN PEMBAHASAN}

Setelah melakukan pre-prosesing data, selanjutnya melakukan training data dengan skenario yang terlah ditentukan pada tabel 2. Proses testing dilakukan dengan mengklasifikasikan data uji yang dipilih secara acak sehingga menghasilkan nilai accuracy, precision, recall, dan f1score yang ditunjukkan pada Tabel 3 .

Table 3. Hasil Pengujian Penerapan Algoritma CNN

\begin{tabular}{|c|c|c|c|c|c|c|}
\hline \multirow[b]{2}{*}{ Skenario } & \multirow[b]{2}{*}{ Label } & \multicolumn{5}{|c|}{ F1- } \\
\hline & & Precision & Recall & Score & Support & Accuracy \\
\hline \multirow{3}{*}{$\mathrm{S} 1$} & Mask & 0.97 & 0.91 & 0.94 & 96 & \multirow{3}{*}{0.94} \\
\hline & Non & & & & & \\
\hline & Mask & 0.92 & 0.97 & 0.94 & 104 & \\
\hline \multirow{3}{*}{$\mathrm{S} 2$} & Mask & 0.98 & 0.94 & 0.96 & 48 & \multirow{3}{*}{0.96} \\
\hline & Non & & & & & \\
\hline & Mask & 0.94 & 0.98 & 0.96 & 52 & \\
\hline \multirow{3}{*}{$\mathrm{S} 3$} & Mask & 0.98 & 0.90 & 0.93 & 96 & \multirow{3}{*}{0.94} \\
\hline & Non & & & & & \\
\hline & Mask & 0.91 & 0.98 & 0.94 & 104 & \\
\hline \multirow{3}{*}{$\mathrm{S} 4$} & Mask & 0.96 & 0.94 & 0.95 & 48 & \multirow{3}{*}{0.95} \\
\hline & Non & & & & & \\
\hline & Mask & 0.94 & 0.96 & 0.95 & 52 & \\
\hline
\end{tabular}

Confusion Matrix dari klasifikasi tersebut dijelaskan untuk memberikan informasi tentang TP (mask positif), FP (non mask positif), TN (mask negatif), dan FN (non mask negatif). Hasilnya dapat dilihat pada gambar 2,3,4 dan 5 .

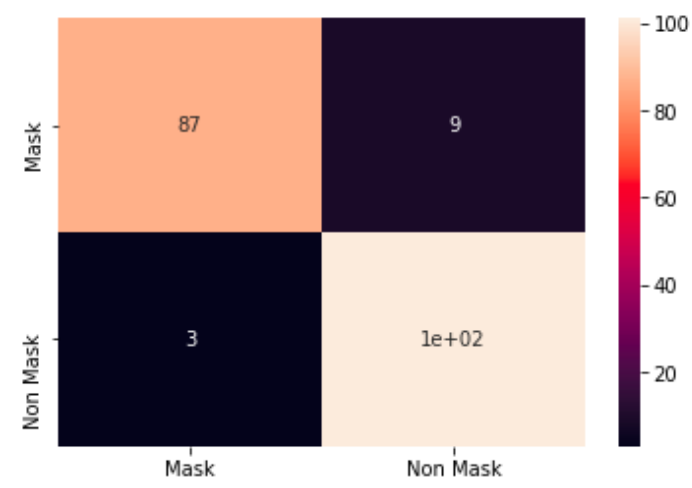

Gambar 2. Confusion Matrix Skenario 1

Hasil confusioan matrix skenario satu pada gambar 2, menunnjukan rasio dari mask positif $91 \%$, mask negatif $9 \%$, non mask negatif 3\% dan non mask positif $97 \%$.

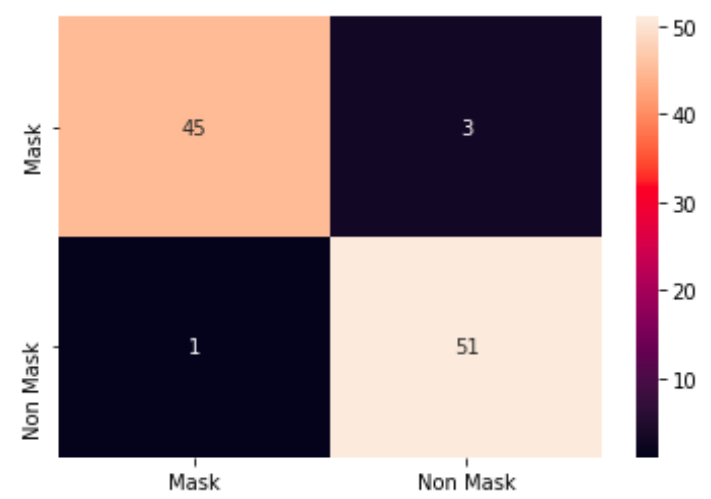

Gambar 3. Confusion Matrix Skenario 2

Hasil confusioan matrix skenario dua pada gambar 3, menunnjukan rasio dari mask positif $94 \%$, mask negatif $6 \%$, non mask negatif $2 \%$ dan non mask positif $98 \%$.

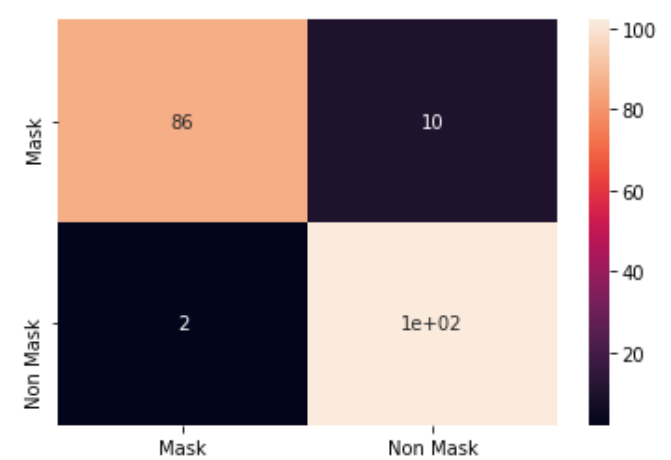

Gambar 4. Confusion Matrix Skenario 3 
Hasil confusioan matrix skenario tiga pada gambar 4, menunnjukan rasio dari mask positif $90 \%$, mask negatif $10 \%$, non mask negatif $2 \%$ dan non mask positif $98 \%$.

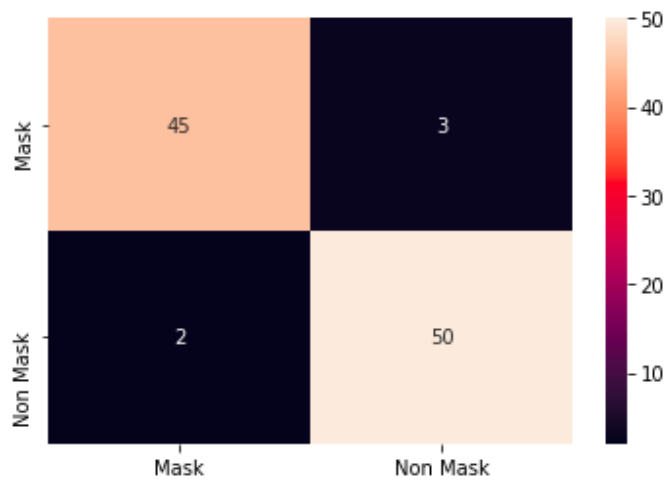

Gambar 5. Confusion Matrix Skenario 4

Hasil confusioan matrix skenario empat pada gambar 5, menunnjukan rasio dari mask positif $94 \%$, mask negatif $6 \%$, non mask negatif $4 \%$ dan non mask positif $96 \%$.

Berdasarkan hasilklasifikasi gambar menggunakan algoritma CNN dengan empat skenario yang telah ditentukan sehingga diperoleh hasil perbandingan dari nilai accuracy seperti pada gambar 6 .

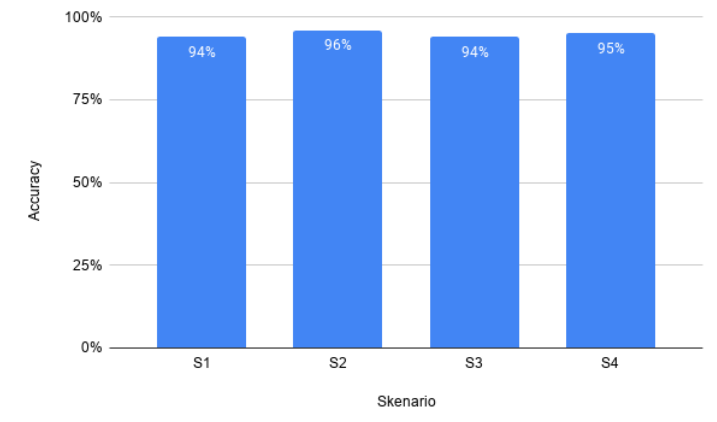

Gambra 6. Perbandingan Hasil Klasifikasi

\section{SIMPULAN DAN SARAN}

Pada penelitian ini kami telah melakukan klasifikasi gambar wajah dengan kelas mask dan non mask. Proses klasifikasi dilakukan dengan beberapa skenario menggunakan algoritma CNN. Dari hasil pengujian menunjukkan skenario kedaua dengan rasio dataset 90:10 dan jumlah epoch 50 mendapatkan nilai accuracy terbaik yaitu 96\%. Selanjutnya skenario empat dengan accuracy $95 \%$ dan skenario satu dan tiga dengan nilai accuracy $94 \%$.

\section{DAFTAR PUSTAKA}

Astiningsih, H., Kurniawan, B., \& Suroto. (2018). Hubungan Penerapan Program K3 Terhadap Kepatuhan Penggunaan Apd Pada Pekerja Konstruksi Di Pembangunan Gedung Parkir Bandara Ahmad Yani Semarang. Jurnal Kesehatan Masyarakat (e-Journal), 6(4), 300-308.

Chaiyasarn, K., Khan, W., Ali, L., Sharma, M., Brackenbury, D., \& DeJong, M. (2018). Crack Detection in Masonry Structures using Convolutional Neural Networks and Support Vector Machines. International Symposium on Automation and Robotics in Construction (ISARC 2018), 118-125. https://doi.org/doi.org/10.22260/ISA RC2018/0016

Chen, H., Tong, R., Chen, M., Fang, Y., \& Liu, H. (2018). A Hybrid Cnn-Svm Classifier For Hand Gesture Recognition With Surface Emg Signals. 2018 International Conference on Machine Learning and Cybernetics (ICMLC), 619-624. https://doi.org/10.1109/ICMLC.2018. 8526976

Fang, W., Ding, L., Zhong, B., Love, P. E. D., \& Luo, H. (2018). Automated detection of workers and heavy equipment on construction sites: A convolutional neural network approach. Advanced Engineering Informatics, 37(May), 139-149. https://doi.org/10.1016/j.aei.2018.05. 003

Fang, W., Zhong, B., Zhao, N., Love, P. E. D., Luo, H., \& Xue, J. (2019). A deep learning-based approach for mitigating falls from height with 
computer vision: Convolutional neural network. Advanced Engineering 39(December 2018), 170-177. https://doi.org/10.1016/j.aei.2018.12. 005

Moolayil, J. (2019). Learn Keras for Deep Neural Networks. https://doi.org/https://doi.org/10.1007 /978-1-4842-4240-7

Patil, N. M., \& Nemade, M. U. (2017). Music Genre Classification Using MFCC , K-NN and SVM Classifier. 4(2), 43-47.

Wang, Yaqi, Sun, L., Ma, K., \& Fang, J. (2018). Breast Cancer Microscope Image Classification Based on CNN with Image Deformation. 15th International Conference Image Analysis and Recognition ICIAR 2018, 1 ,

845-852. https://doi.org/10.1007/978-3-31993000-8

Wang, Yu, Chen, Y., Yang, N., Zheng, L., Dey, N., Ashour, A. S., ... Shi, F. (2018). Classification of mice hepatic granuloma microscopic images based on a deep convolutional neural network. Applied Soft Computing Journal.

https://doi.org/10.1016/j.asoc.2018.10 .006

Zufar, M., \& Setiyono, B. (2016). Convolutional Neural Networks untuk Pengenalan Wajah Secara Real Time. Jurnal Sains Dan Seni ITS, 5(2), 72-77. 